\title{
ブロー液が有効であった悪性外耳道炎例
}

\author{
今石 寛昭 ${ }^{1)} \cdot$ 永沼 久夫 ${ }^{1)} \cdot$ 吉澤 朝弘 $^{2)} \cdot$ 山地 誠一 3$)$
}

\section{A Case of Malignant External Otitis for Which Burow's Solution was Effective}

\author{
Hiroaki Imaishi and Hisao Naganuma \\ (Kin-ikyo-chuo Hospital) \\ Tomohiro Yoshizawa \\ (Kin-ikyo Sapporo Nishiku Hospital) \\ Seiichi Yamaji \\ (Kin-ikyo Sapporo Minami Clinic)
}

\begin{abstract}
A patient who was undergoing treatment for diabetes developed necrotizing external otitis due to Pseudomonas aeruginosa infection. The patient was a 75-year old man, and the main complaint were earache and otorrhea of the right ear. Daily intravenous antibiotic administration and ear examination were performed after hospitalization. However, because control of inflammation was not achieved, Burow's solution was used. Otorrhea improved following administration two times. Because granulation tissue was reduced, we discharged the patient.

Burow's solution was effective for malignant external otitis.
\end{abstract}

Key words : malignant external otitis, Burow's solution, Pseudomonas aeruginosa

\section{はじめに}

悪性外耳道炎は1968 年 Chandler ${ }^{1)}$ により最初に報告さ れた。高齢者に発症し糖尿病, 緑膿菌感染, 骨破壊とい ら特徴をもち, 難治性で進行性の経過をとり, 外耳道周 囲の軟骨，骨を破壊して時に頭蓋内にまで炎症が波及し 致死的となる壊死性変化の強い外耳道炎である.

われわれは，糖尿病を基礎疾患にもち緑膿菌感染によ る外耳道炎を発症し，治療に難渋した症例を経験したの で報告する。

\section{症例}

症例：75 歳, 男性.
主訴: 右耳痛, 耳漏, 耳閉感.

現病歴: 2004 年 5 月 1 日頃より右耳痛, 耳漏, 耳閉感 あり. 5 月 6 日近医受診し加療を受けるも症状が改善し ないため, 5 月 21 日勤医協札幌西区病院耳鼻咽喉科を受 診した. 外来にて抗生物質の内服, 点耳薬投与等の加療 が行われたが炎症のコントロール不良のため, 5 月 24 日 当院紹介入院となった。

既往症: 2 型糖尿病, 高血圧症, 高脂血症, 前立腺肥大症. 家族歴：特記すべきことなし.

画像所見：CT では外耳道に軟部組織陰影および，一 部に軽度の外耳道骨破壊像を認めた。

乳突峰巣の発育は良好, 内部に一部浸出液を疑う陰影

1）勤医協中央病院耳鼻咽喉科

2）勤医協札幌西区病院耳鼻咽喉科

3）勤医協札幌みなみ診療所 


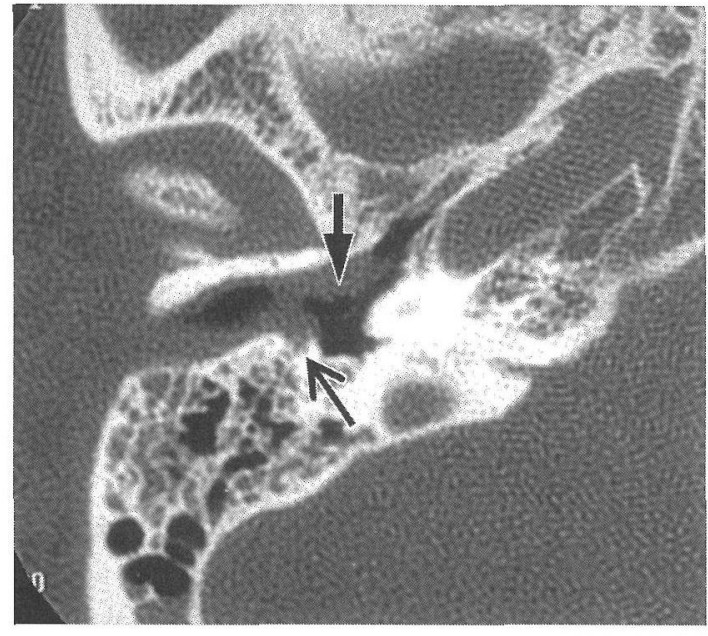

図 1 CT 所見

外耳道内に軟部組織陰影および，外耳道後壁の一部に骨 破壞像を認めた。

軟部組織陰影（矢印上）

外耳道の骨破壊像（矢印下）

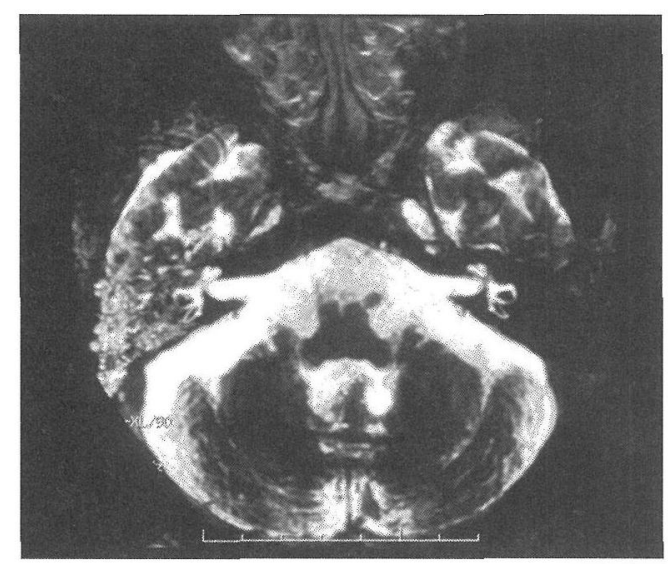

図 2 MRI 所見（T2 強調画像）

乳突峰巣に高信号に描写される浸潤陰影を認めた。

を認めた（図 1)。MRI では乳突峰巣に T2 強調画像で高 信号に描写される浸潤陰影を認めた。外耳道病変はMRI 上はっきりしなかった（図 2)。なおテクネシウム，およ びガリウムシンチグラムは行わなかった。

入院後の経過 : 入院時血液データは白血球数, CRP の 有意な上昇は認めなかった。

血糖值は HbAlc 6.6\%, 空腹時血糖 $100 \mathrm{mg} / \mathrm{dl}$ 台のた め，インスリン，経口剤等は使用せず，血糖コントロー ルは食事療法のみで行った。

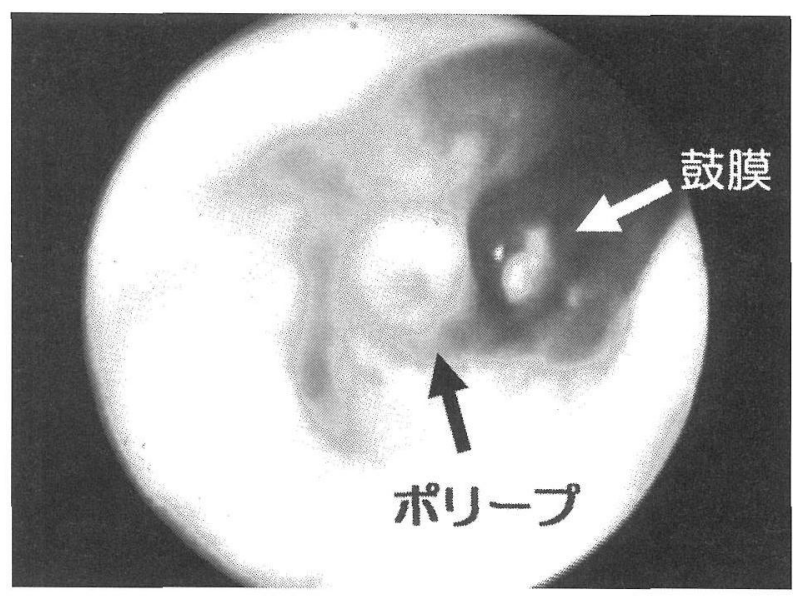

図 3 入院時の外耳道所見

膿性耳漏および後下壁にポリープ様病変を認めた。

入院時の外耳道所見では，膿性耳漏および後下壁にポ リープ様病変を認めた（図 3). 鼓膜は外耳道ポリープの ため全容の観察は困難で，穿孔等の所見は明らかでな かった。なお前医で行われた耳漏の培養検查では，多量 の緑膿菌および少量のクレブシエラが認められた。

抗生物質（PIPC $2 \mathrm{~g} /$ 日）の点滴静注とともに，局所治 療としては連日過酸化水素水やイソジン水溶液を用いて 耳洗浄を行い抗菌剤の点耳薬は使用しなかった。あわせ て外耳道内に認めたポリープ様組織の切除を行った。切 除組織の病理結果は肉芽組織で悪性所見は認めなかっ た。疼痛のためポリープ様組織は少量ずつ切除をすすめ た。しかしなかなか正常な上皮化がみられず，外耳道の 乾燥化むみられないため，患者さんへブロー液の使用を 提案し了承を得た。ブロー液は寺山5) の報告に準じて当 院薬剤部で作製した13\%酢酸アルミニウム溶液を使用し た.6月 19 日最初ブロ一液の湿綿球を試験的にあてたが, 疼痛を認めないためすぐ耳浴に切り替えた。 その後耳漏 は改善傾向を呈し，6月 21 日 2 回目の投与にて耳内乾燥 化がタられ，肉芽病変も縮小傾向になったため 6 月 26 日 退院し外来フォローとした。また，純音聴力検査では入 院時に軽度の混合性難聴を認めていたが，退院時には気 導骨導差は改善し，かつブロー液投与による骨導の低下 は認められなかった（図 4)。退院後週 1 回ブロー液耳浴 を継続, 合計6回投与で肉芽組織の消失にいたった(図5).

\section{考察}

悪性外耳道炎は 1968 年 Chandler ${ }^{1)}$ にり最初に報告さ 

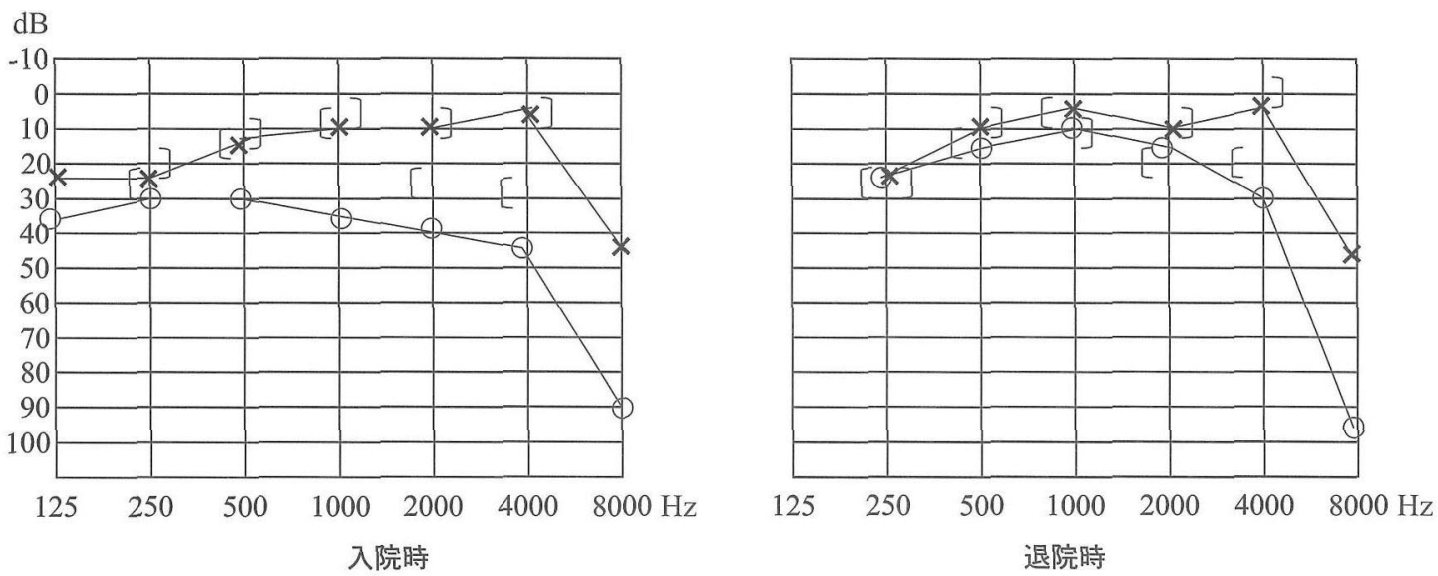

図 4 入院時および退院時の純音聴力検查結果

入院時は軽度の混合性難聴を認めていたが，退院時には気導骨導差は己改善し，からブロー液投与による骨導の低下は認められな かった。

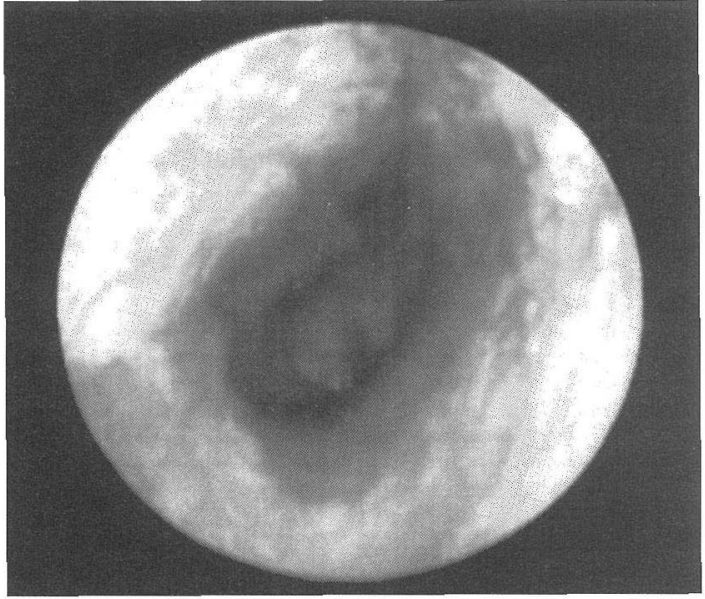

図 5 治療後の外耳道所見

入院時に認めた耳漏, およびポリープ様病恋は消失した。

れた。悪性壊死性外耳道炎（necrotizing external otitis） とも呼ばれ，糖尿病，緑膿菌感染，骨破壞々いう特徵を もち病態的には局所的な皮膚炎加ら蜂窩織炎,骨軟骨炎, さらに最終的には骨髄炎へと移行する。難治性で進行性 の経過をとり，時として致死的となる壞死性変化の強い 外耳道炎である。当時は緑膿菌汶対する適切な抗生物質 が少ないこともあり予後不良の疾患であったが, 最近で は抗生物質の普及や疾患に対する認識む高まり，予後は 改善傾向を示している.

治療の基本は厳密な糖尿病のコントロールおよび抗生 物質の全身投与と局所治療である. 原因菌（特に緑膿菌）
に刘する抗生物質治療としては，第 1 選択としてアミノ 配糖体抗生物質と, 緑膿菌に感受性を有するペニシリン 系あるいはセファロスポリン系抗生物質の併用が䳸めら れている。この方法では 2 剂の相乗効果と同時に耐性菌 の出現む予防するといわ机ている。ただしアミノ配糖体 抗生物質の使用にあたっては腎毒性, 聴器毒性に十分注 意が必要である。この代替療法としてニューキノロン系 抗生物質の大量投与がある。これは経口投与のため入院 治療を行わない症例に適応とされる2⿰.

局所治療では，外耳道の肉芽増生が持続する場合は局 所清掃とともに肉芽の鉗除が必要である。われわれも， 抗生物質の点滴静注，および連日の過酸化水素水やイソ ジン水溶液等を用いた耳浴・耳洗浄, 肉芽組織の䤵除を 行った。しかし数週間の治療にもかかかららず局所の炎症 のコントロールがつかないため，ブロー液の投与を検討 した.

ブロー液は 19 世紀の医師 Karl August von Burow の考 案した $13 \%$ 酢酸アルミニウム液である。当初は点耳液や, 希䣋して皮膚外用戍，含嗽剂として使用されてきたよう だが，抗生物質の普及により使用頻度は減少し，ごく最

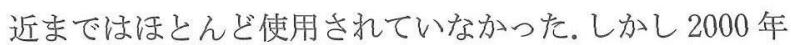

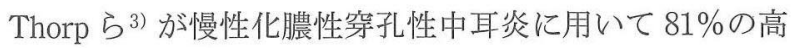
い治癒率が報告されて以来，中耳・外耳の難治性慢性感 染症に有効との報告がなされている(4) 7).

作用機序について Thorp ら ( $^{8)}$ は本剂の酸性度 (pH3.06) と，酢酸アルミニウムの作用を述べているのみである。 
酸性度については, pH3.5 の強酸性水は細菌・ウイルス などの酵素活性を阻害し，結果感染性を消失させるとの 報告がある ${ }^{9}$. もともと糖尿病患者は耳垢の $\mathrm{pH}$ が正常者

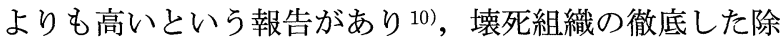
去に加えてブロー液の強酸性が糖尿病患者にみられる細 菌の生育に好条件な $\mathrm{pH}$ の上昇を阻害するために有利に 働いたと思われる。一方酢酸アルミニウムの作用として, 局所のタンパク質に接してタンパク金属複合体を形成す ることにより殺菌，収斂，分泌抑制などが発現すると考 えられている11). 本症例もこのような酸や化学的殺菌作 用その他の作用が総合的に功を奏したものと考えられ た.

慢性外耳道炎，外耳道湿疹，慢性穿孔性中耳炎，慢性 肉芽性中耳炎など中耳・外耳の難治性慢性感染に対する ブロー液の効果は, 諸家の報告では治癒率で $70 \sim 80 \%$, 改善率も含めると $90 \%$ 以上と高率で，しかも細菌，真菌 の種類を問わず，特に耐性菌や緑膿菌などの難治なもの にも有効であるという利点が挙げられる．さらにその効 果発現の早さもその特徵である。寺山ら7) は病悩期間 2 週間から 20 年（平均 3.78 年）の 25 耳の検討で， $1 \sim 2$ 回の投与で効果発現し, 治癒症例の 20 例の治癒期間は 3 日から 3 週間であったと報告している.

なお本症例では画像検査で乳突蜂巣内に浸潤影を認め たことから，外耳道炎から中耳への炎症の波及が疑われ た。波及経路は外耳道破壊部分，あるいは当初ポリープ により観察困難であったが鼓膜穿孔をきたし中耳へと波 及した可能性が考えられた。 結果としてブロー液投与に よる内耳への影響も否定できなかったが，ポリープ組織 を減量し鼓膜全容が観察された時期には鼓膜穿孔はみら れず，文献上もブロー液は慢性穿孔性中耳炎等にも有効 で，聴力の悪化等の重篤な合併症の報告も現在のところ

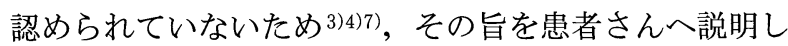
同意の上ブロー液の投与に踏み切った.

以上のように中耳・外耳の難治性慢性感染に対するブ ロ一液の効果は多くの報告がみられるが，覀性外耳道炎 に対する治療効果についてはこれまであまり言及された ものはない，渉編しえた範囲では石永ら ${ }^{12)}$ が抗生物質と 併用で治癒したとの報告があるのみである.

前述のように悪性外耳道炎は，糖尿病の基礎疾患の上 に発症する壊死性変化の強い外耳道炎である，感受性を 有する抗生物質でも, 数週間, 時化数力月もの長期投与 を要することもあるともいわれている難治性感染症であ
る. 本症例から, 菌種を問わない強力な殺菌作用と効果 発現の速さを期待して，一般的な保存的治療に抵抗する 悪性外耳道炎の治療としてブロー液の使用は有効な一法 であると思われた。

\section{まとめ}

1）緑膿菌感染による外耳道炎を発症した糖尿病罹患 患者で，治療に難渋した症例を経験した。

2）ブロー液は中耳・外耳における難治性慢性炎症に有 効であるとされているが，治療に抵抗する悪性外耳道炎 にも効果が期待できると考えられた。

\section{参考文献}

1) Chandler JE : Malignant external otitis. Laryngoscope 78 : $1257 \sim 1294,1968$.

2) 原田勇彦：墨性外耳道炎の現状. JOHNS $14: 1069 \sim 1073$, 1998.

3) Thorp MA, Gardiner IB and Prescott CA : Burow's solution in the treatment of active mucosal chronic suppurative otitis media: determining an effective dilution. J Laryngol Otol 114 : $432 \sim 436,2000$.

4）柏村正明:外耳・中耳の慢性感染症に対するBurow's solution の効果について，北耳報 $102: 11 〜 16 ， 2003$ 。

5）寺山吉彦：鼓膜炎，外耳道炎の治療と Burow 液. JOHNS $20: 1715 \sim 1718,2004$.

6）酒井 昇：難治性慢性耳漏に対する一治療法の試み。耳鼻 $51: 11 \sim 15,2005$

7）寺山吉彦，滝沢昌彦，後藤田裕之，他：難治性の外耳道お よび中耳の化膿性炎に対するブロー液の使用経験。日耳鼻 $106: 28 \sim 33,2003$.

8) Thorp MA, Kruger J, Oliver S, et al. : The antibacterial activity of acetic acid and Burow's solution as topical otological preparations. J Laryngol Otol $112: 925 \sim 928,1998$.

9）清水義信，岩田宗高：超酸性水の殺菌・殺ウイルスメカニ ズム. INFECTION CONTROL $8: 756 \sim 759,1999$.

10) Driscoll PV, Ramachandrula A, Drezner DA, et al. : Characteristics of cerumen in diabetic patients: a key to understanding malignant external otitis? Otolaryngol Head Neck Surg 109 : $676 \sim 679,1993$.

11）矢萩秀人，佐藤誠二：難治性の外耳道炎および中耳の化膿 性疾患に対するブロ一氏液の使用経験。月刊薬事 $46: 211$ $\sim 216,2004$

12）石永 一，立松正規，湯田厚司，他：悪性外耳道炎の 1 例. 日耳鼻 $107 ： 567 ， 2004$.
原稿受付: 平成 17 年 6 月 6 日

原稿採択 : 平成 17 年 7 月 27 日

別刷請求先：今石寬昭

厂007-8505 札幌市東区伏古10条 2 丁目 15-1

勤医協中央病院耳鼻咽喉科 